\title{
Editorial
}

\section{Knowledge As Capital/Capital As Knowledge}

Knowledge is increasingly being recognized as the dominant, the most potent and the 'true' form of capital. Economies rooted in knowledge and living in knowledge, with all of its socio-organizational requisites, are surpassing those societies that are only rich in raw materials, labor, money or land. Strategic resources are no longer coming out of the ground, but out of human minds.

Even Peter F. Drucker recently [3] acknowledged that 'knowledge has become the capital of a developed economy, and knowledge workers the group that sets society's values and norms.' Earlier popular treatments of knowledge as capital include works of Sowell [5]. More rigorous theoretical background for this concept was advanced by Dewey [2] and also elaborated into a new synthesis by this author [6].

In order to understand knowledge as capital (and vice versa), it is necessary to achieve a newer and sharper understanding of the concept itself. No other concept is so confused, even to the point that capital to some is anything useful in production. Capital is obviously not a pile of money, stock of accumulated goods or possessions and certainly not assets or funds. (Capital assets are capital assets, not capital.)

Capital should also not be equated with the results of the capital formation process, when it is the process itself that is at the crux of the matter. Capital must be viewed as an organization, a form of invariant relationship between human producers and the changing structure of specialized means of production (capital assets).

It is quite clear that capital assets in themselves are 'dead', inert and unproductive - they cannot be capital. Something else makes them come 'alive' and become an integral part of the production process. That 'something else' is necessarily the capital, but we still have to specify what it is.

First, we have to realize that any business enterprise is engaged in at least two kinds of production: (1) the production of something else than itself (product, service), i.e. poiesis, and (2) the production of itself (company's own knowledge/technological matrix), i.e. autopoiesis. Institutional autopoiesis clearly is the necessary prerequisite for the institutional poiesis.

The self-production of business has never been ex-

IOS Press

Human Systems Management 9 (1990) 129-130 plicitly considered by economists and economics, only the production of external goods and services. Selfproduction has always been taken as given or automatic. Yet, in the modern world of global com petition it is the self-production of business, the renewal of knowledge, technology and processes, which counts more than any specific product or service produced in a given and isolated production cycle.

Second, both capital and production are interrelated in holistic reproduction process, including both production and self-production:

$$
\ldots \mathrm{P} \rightarrow \mathrm{C} \rightarrow \mathrm{P} \rightarrow \mathrm{C} \rightarrow \mathrm{P} \rightarrow \mathrm{C} \ldots
$$

Depending on how we choose to unravel the above closed and cyclical process, we shall correspondingly identify two forms and two functions of 'capital': (1) its 'dead' form, a speculative artifact seeking its own simple expansion,

$$
\mathrm{C} \rightarrow \mathrm{P} \rightarrow \mathrm{C}^{+},
$$

where production is just the means, serving the capital, ignoring the customer and degrading the production process, or (2) its 'live' form, natural catalyst and enhancer of the production,

$$
\mathrm{P} \rightarrow \mathrm{C} \rightarrow \mathrm{P}^{+},
$$

where production and its improvement is the customer-driven purpose of business and capital is only the means.

Here it is appropriate to quote Henry Ford [4]:

Money put into business as a lien on its assets is dead money. When industry operates wholly by the permission of 'dead' money, its main purpose becomes the production of payments for the owners of that money. If quality of goods jeopardizes these payments, then the quality is cut down. If full service cuts into the payments, then service is cut down. This kind of money does not serve business. It seeks to make business serve it. Live money in a business is usually accompanied by the active labour of the man or men who put it there. Dead money is a sucker-plant.

Thirdly, capital is the enduring organizational matrix of productive power that is perpetuated through its own self-renewal even though individual components (capital assets) wear out and are replaced by different types of capital assets. Capital is the knowledge matrix that must be properly regenerated so that the individual capital asset items can be properly embedded within it.

To explain capital productivity, one has to explain the growth of knowledge itself [2]. Somehow, econo- 
my 'knows' how to create the better set of men and machines before undertaking the task of renewal. Where does this knowledge come from? This 'knowledge' must be both an input and an output in the production process.

It is the existence of this body of knowledge (or knowledge matrix) that makes capital accumulation possible.

J.B. Clark has best captured the nature of capital already in 1889 [1]:

'The bodily tissue of capital lives by destruction and replacement; the utility that is the vital essence of it is, in successful industry, perpetual.'

Human knowledge and its continually enhanced renewal is the main source of income and value growth. The only societies which have ever had enough capital accumulation are those characterized by continuous knowledge and innovation growth. Marxist labor theory of value is an intellectual artifact belonging to theology rather than economics.

However, this marxian 'theology' is unfortunately perpetuated today in Central Europe, where the so called reformists totally ignore the role of knowiedge as capital and simply replace marxist labor by pseudomarxist money.

Dewey's [1] teaching is quite ignored 'overthere', even though it is quite clear and self-evident 'overhere':

Consumer welfare cannot be perceptibly increased by an addition to the stock of money.

Capital must satisfy all three of the following criteria:

(1) must be capable of being bought, sold, transferred or held for disposition ; and

(2) must be capable of being used, deployed or consumed; and

(3) must remain available for further production cycle.

Only knowledge can be stored and consumed and still remain available for future use. Knowledge is capital and it is the only form of capital in existence. All other factors are simply capital assets which are necessarily used up through consumption. Money is not capital at all, but simply a means and measure for acquiring and maintaining both capital (knowledge) and capital assets (money, plant \& equipment, natural resources, land and labor).

Land cannot be cultivated, labor applied, technology used and money spent - without knowledge. However, all other forms of capital can be derived from and driven by knowledge. Knowledge - and knowledge alone - is capable of creating wealth. It produces and then uses all other forms of capital as the means of its own self-enhancement.

It remains to be specified what is meant by 'knowledge'. It is obviously not the data, information or any printed or recorded documents. Knowledge is inseparable from the process of knowing: Knowledge is a process.

What do we mean by saying that somebody knows? That we expect that person to be capable of coordinated action towards some objectives. Coordinated action is the proof of the possession of knowledge. Knowledge without action reduces to 'dead' information or data All doing is knowing, and all knowing is doing.

The vast repositories of data and information (data banks, encyclopedias, 'wise men of the mountain') are just passive recordings, the 'raw material' of knowledge. Only coordinated human action, i.e., the process of relating such components into coherent patterns, which turn out to be successful in achieving goals and purposes, should qualify as knowledge: Bringing forth a world of coordinated action is human knowledge.

Separation of knowing from doing (knowledge from action) in the sense of 'some know and others act', like the separation of managers (coordinators) from the doers (workers), is a self-inflicted wound of decadent management.

Capital is that part of the results and proceeds of production that has to be maintained, reproduced or produced in order to realize the next production cycle.

Capital asset is that part of the harvest that is set aside for the next season planting. Productive power of the soil, maintained, produced or recovered by tillage, drainage or fertilization, is capital asset. The revenues 'ploughed back' into the production process is capital asset. The machine park, maintained, replaced or aded, is capital asset. Labor, reproduced, expanded or maintained is capital asset. The knowledge necessary for realizing the production process, with properly maintained, expanded or produced capital assets, is capital.

Capital is the catalyst of production: it persists, it is preserved and yet it enters and enhances the process.

Conscious and purposeful autopoiesis of business is the strategic imperative of the new era. Only a few are informed, prepared and willing.

\section{References}

[1] J.B. Clark, 'Capital and Its Earnings,' Publications of the American Economic Association, III (1889), p. 98

[2] Donald Dewey, Modern Capital Theory, Columbia University Press, New York, 1965.

[3] Peter F. Drucker, The New Realities, Harper \& Row, New York 1989, pp. 174-175.

[4] Henry Ford, Today and Tomorrow, Doubleday, Page and Co., Garden City, NY, 1926; reprinted by Productivity Press, Cambridge, MA, 1988.

[5] Thomas Sowell, Knowledge and Decisions, Basic Books, New York, 1980.

[6] Milan Zeleny, 'Knowledge as a New Form of Capital: Part 1. Division and Reintegration of Knowledge,' Human Systems Management, 8 (1989) 1, pp. 45-58; Part 2. Knowledge-Based Management Systems,'Human Systems Management, 8 (1989) 2, pp. 129- 143.

Milan ZELENY

Graduate School of Business

Fordham University at Lincoln Center New York, NY 10023

USA 